\title{
Market Power in the Poultry Sector in Turkey
}

\author{
Gökhan Özertan* \\ Boğaziçi University
}

\author{
Sayed Saghaian** \\ University of Kentucky
}

\author{
Hasan Tekgüç*** \\ Mardin Artuklu University
}

\begin{abstract}
In 2009, the Competition Authority (CA) in Turkey penalized 27 broiler chicken producers for agreeing to restrict supply and controlling prices, hence forming a cartel. The CA based its punishment decision on communication records among major broiler chicken producers, using raw price series and without any statistical or econometric analysis. In this research, time-series methods are employed to test directly for the presence of market power along the supply chain in the poultry sector for both demand and supply sides. The findings show that the retail price behavior in the poultry supply chain in Turkey is consistent with an oligopolistic market structure.
\end{abstract}

Keywords: market power, poultry, Turkey.

\section{Türkiye Kanatlı Sektöründe Piyasa Gücü}

\section{Özet}

Rekabet Kurumu (RK), 2009 yılında 27 etlik piliç üreticisini arzı kısma ve fiyatları kontrol etme üzerinde anlaşarak kartel oluşturmaları sebebiyle cezalandırmıştır. RK, ceza kararını belli başlı etlik piliç üreticilerinin aralarında yapmış oldukları görüşme kayıtlarına ve ham fiyat verilerine istinaden vermiş olup herhangi bir istatistiksel ya da ekonometrik analizden faydalanmamıştır. Bu araştırmada, zaman serisi yöntemleri kullanılarak etlik piliç sektörü arz zincirinde piyasa gücü hem arz hem de talep açılarından test edilmiştir. Sonuçlar, etlik piliç arz zincirindeki perakende fiyat davranışlarının oligopolistik piyasa yapısı ile tutarlı olduğunu göstermektedir.

Anahtar kelimeler: piyasa gücü, kanatl sektörü, Türkiye.

$\mathrm{T}$

The poultry sector worldwide has shown itself to be much more suitable to the adaption of modern breeds and production methods than the cattle, mutton, or goat sectors. This is mostly due to the highly integrated nature of the broiler industry, where the modern production process is organized totally in the closed environs of factory farms. Moreover, a feed conversion ratio is more favorable to the chicken

\footnotetext{
* Gökhan Özertan is an Associate Professor in the Department of Economics at Boğazici University, 34342, Bebek, İstanbul, Turkey. E-mail: ozertan@boun.edu.tr

** Sayed Saghaian is an Associate Professor in the Department of Agricultural Economics at the University of Kentucky, 314 C.E. Barnhart Building, Lexington, KY, 40513, U.S.A. Email: ssaghaian@uky.edu

*** Hasan Tekgüç is an Assistant Professor in the Department of Economics at Mardin Artuklu University, 47100, Mardin, Turkey. E-mail: htekguc@gmail.com
} 
market compared to the red meat market (cattle, mutton, and goat). This has made factory-raised broiler chicken considerably cheaper than red meat. Due to these cost advantages and an aversion to red-meat relating to health issues, the share of poultry in meat-product consumption has been increasing in Turkey as it has in the rest of the world (FAOSTAT, 2013).

In 2009, the Turkish Competition Authority (CA) fined 27 broiler chicken producers that control the majority of the market share for trying to fix prices and quantities and forming a cartel during the period of 2003-2008. The CA found evidence that producers manipulated the market by concurrently decreasing supply and increasing prices. This research supplements the CA study that relied only on communication records and prices charged using an econometric analysis and direct investigation of market power by buyers. We employ a model developed by Lloyd et al. (2009) that tests for the presence of both seller and buyer power (i.e. supermarket chains). The Lloyd et al. (2009) methodology is suitable for this purpose because it requires only price data (i.e., from producers and retailers; there being no monthly quantity data available on the poultry sector in Turkey), and it allows us to account for intermediaries (in this case the broiler processing firms targeted by the CA) with a marketing cost index. In return, this methodology is only a "first pass" test in the sense that it can point out the direction (whether related to retailers or producers) for further inquiry into buyer or seller power. Erdoğan et al. (2012) argue that big retailers have increased their market share for food in recent years. Also, the visual inspection of price series (presented below) points to a widening of the poultry producer-retail price spread. This we believe has important welfare implications. Hence, we focus on the retailers' buyer power in this study. In addition, we also use historical decompositions to investigate the price behavior of the broiler chicken market between 2003 and 2013.

\section{Poultry Sector in Turkey: The Competition Authority Accusation and Decision}

In 2012, the poultry sector accounted for half of all the meat consumption in Turkey. The estimated total revenue of the broiler industry in Turkey was about eight billion Turkish Lira (TL), roughly 4.4 billion USD ( by 2012 exchange rates). ${ }^{[1]}$ The major poultry producers in Turkey are vertically integrated where they raise the broiler chickens, slaughter them, and have their own distribution channels. They also, to differing degrees, sub-contract raising broiler chickens.

In 2008, the CA accused 27 broiler chicken producers of forming a cartel. Nine of the largest producers accused had a market share of 75 to $80 \%$ in the period 2004-2008. In August 2008, the CA started the investigation and in November 2009 the final decision was announced. The accusation was that the broiler chicken producers had started engaging in anti-competitive actions back in 2003. So charged, the producers claimed

[1] Authors' estimation based on BESD-BIR (Turkish Poultry Meat Producers and Breeders Association) production estimates and TurkStat (2013a) price estimates. 
that they had merely talked among themselves during consultations and had never taken any concerted action to influence the quantities supplied or the prices levied. The CA based its decision on communication records among the major producers using only the raw price series without any statistical or econometric analysis. At the end, the CA found evidence that within the period 2003-2008, the producers had taken joint actions in the forms of decreasing supply, increasing exports, and increasing domestic prices. The CA decided that the actions taken by the producers violated the competition law and therefore penalized them (Turkish Competition Authority, 2009).

In analyzing the CA's arguments, a visual inspection of the price series for the period 2003-2013 reveals that the nominal producer prices hovered around $2 \mathrm{TL} / \mathrm{kg}$ between 2003 and 2009. It seems that broiler producers were able only to keep nominal prices from sliding down further. If we consider the inflation (around $10 \%$ annually during those years), the producer price for broiler chicken was actually declining between 2003 and 2008 when the cartel was active (see Figure 1). Finally, the producer prices increased by $43 \%$ in a single month at the beginning of 2011 . The natural logs of chicken prices discussed above are presented in Figure 1.

Figure 1

Monthly Producer (PPRODUCER) and Retail (PRETAIL) Chicken Prices (natural log of TL/ kg) in Turkey between 2003 and 2013

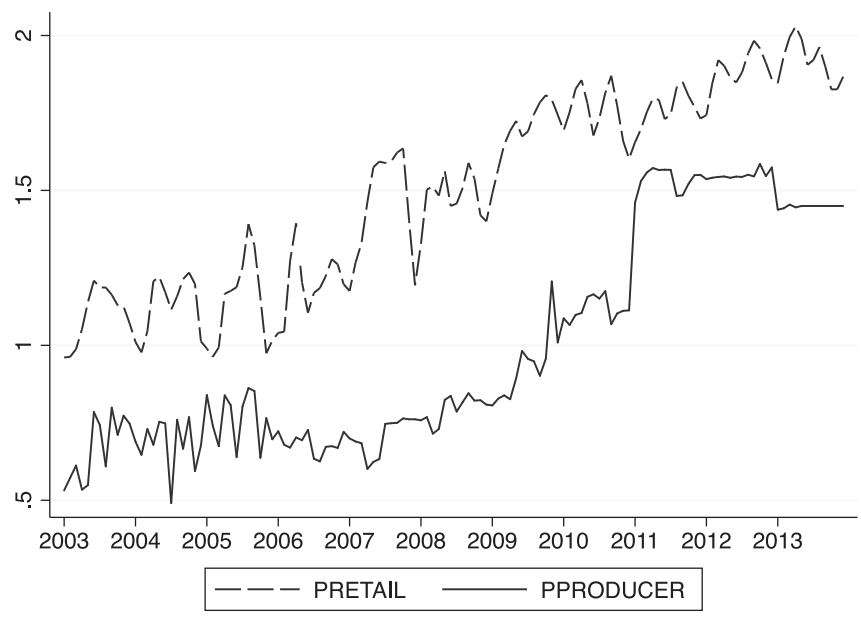

Meanwhile, the visual inspection of the broiler chicken price series suggests that the gross margins between retail and producer prices had persistently increased between early 2006 and late 2010. The jump in producer prices in the beginning of 2011 temporarily narrowed down the gross margins to the 2005 level. However, the producer-retail gross margins have been widening again in recent years. The CA decision does not make it clear whether the broiler chicken industry was fined for its retail or wholesale price 
fixing efforts. Rather, an inspection of the producer and retail price series suggests a more complicated picture. At the producer level, the cartel was unsuccessful in increasing the prices (where most firms are both producers and buyers). At the retail level, even though the cartel was successful in raising prices, not all producers had the same vertically integrated distribution networks. The CA investigation did not include other actors either, noticeably the regional and national supermarket chains. In this paper, we focus on both the producer and the retail ends of the poultry supply chain.

\section{Methodology and Test for Market Power}

\section{Test for Market Power}

The literature on the presence of a concentration and market power, and in particular, on price gauging by intermediaries, has relied on the dynamics of price transmission along the supply chain. Meyer and von Cramon-Taubadel (2004) and Frey and Manera (2007) present a thorough analysis of this literature. On price gauging, Meyer and von Cramon-Taubadel (2004) state that intermediaries pass on price increases to consumers but resist doing so when prices decline whenever they have market power. A more recent methodology has been introduced by Lloyd et al. (2009), which emphasizes that whenever quantity data is not available, a "first-pass test" of market power can be run by using price data only. The analysis is conducted by using marketing costs jointly with exogenous supply and demand shifters in the equation for producer-retail price spread. Noting that, in a perfectly competitive market, demand and supply shocks do not influence the producerretail price margins, then, the presence of statistically significant estimates for demand and supply shifters would indicate the existence of imperfect competition and market power.

Studies that test for market power in food markets are many; for example, Bakucs and Ferto (2005) and Cotterill (2005). However, only a few applications of the Lloyd et al. (2009) analysis to agricultural products are available. Falkowski (2010) tested for market power in the Polish milk sector, Liu (2012) for the Finnish food markets, and Cavicchioli (2010) for the Italian milk sector. A similar test was also used by Kinnucan and Tadjion (2013) for the U.S. beef and pork sectors. As stated in Section 1, no monthly quantity data are available for the poultry sector in Turkey. The Lloyd et al. (2009) model provides a "first-pass test" for these types of cases where only two price series are sufficient to conduct the analysis. In addition, we incorporate a structural break into the Vector Error Correction (VEC) and Lloyd et al. (2009) models in order to take into account a significant increase in producer prices at the beginning of 2011. Finally, we complement Lloyd et al., (2009) with a historical decomposition analysis.

Lloyd et al. (2009) specify that under competitive conditions, the price spread between the producer and the retail levels is solely due to marketing costs (Equation 1). In a perfectly competitive market, retail prices are only influenced by producer prices and marketing costs that include processing-related costs. On the contrary, when the parameter for 'conjectural elasticity' is different from zero, market shocks will have a differential impact in addition to marketing costs at each level in the marketing chain, 
which is an indication of imperfect competition. In this set-up, Lloyd et al. (2009) assume a fixed-proportion production technology, constant returns to scale, a linear marketing cost function, and linear functional forms for the exogenous demand and supply shifters to obtain Equation 2 in reduced form:

$$
\begin{aligned}
& P_{R}=P_{P}+M \text { or } M=P_{R}-P_{P} \\
& P_{R}=\gamma_{0}+\gamma_{1} P_{P}+\gamma_{2} M+\gamma_{3} D+\gamma_{4} S,
\end{aligned}
$$

where $P_{R}$ is retail chicken prices, $P_{P}$ producer chicken prices, $M$ is marketing costs, and $D$ and $S$ are exogenous demand and supply shifters, respectively. We expect that the coefficients have the following signs: $\gamma_{1}>0, \gamma_{2}>0, \gamma_{3}>0$, and $\gamma_{4}<0$. Positive signs are expected for $\gamma_{1}$ and $\gamma_{2}$ since under any condition they contribute to the retail chicken prices. To test for perfect competition, the null hypothesis would be $H_{0}: \gamma_{3}=\gamma_{4}=0$. If the estimated coefficients for the supply and demand shifters are statistically different from zero, then the null hypothesis of perfect competition is rejected. In this case, demand shifters shift the demand curve to the right, widen the margins, and mark up prices above marginal costs. A similar statement is valid for supply shifters.

\section{The Model}

A contemporary approach to quantifying the relationship between the non-stationary I(1) series is to construct a VEC model. A VEC model incorporates cointegration in order to capture the information contained in each series' long-run stochastic trend, and it reflects the fact that the variables are I(1) and must be differenced. Given the sudden jump at the beginning of 2011 in the producer series, we also test for structural breaks in the data. When structural breaks are present, the model is modified by incorporating a vector of dummy variables to capture the impact of structural breaks (we have also included 11 centered monthly dummies to control for the presence of seasonality). Respective trend and intervention dummies are generated following Johansen et al. (2000) and Joyeux (2001). The specification of the VEC model is as follows:

$\Delta \mathrm{X}_{\mathrm{t}}=\alpha_{0}+\sum_{\mathrm{i}=1}^{\mathrm{k}-1} \Gamma_{\mathrm{i}} \Delta \mathrm{X}_{\mathrm{t}-\mathrm{i}}+\Pi \mathrm{X}_{\mathrm{t}-\mathrm{k}}+\rho_{1} t+\rho_{2} D_{t-k}+\rho_{3} D_{t-k} * t+\sum_{\mathrm{i}=0}^{\mathrm{k}-1} \beta_{\mathrm{i}} \Delta \mathrm{D}_{\mathrm{t}-\mathrm{i}}+\sum_{\mathrm{i}=1}^{11} \delta_{\mathrm{i}} s_{\mathrm{i}}+\varepsilon_{t}$

where $\alpha_{0}$ is a vector of intercept terms $\Delta X_{t}$ is a matrix of chicken price variables and other variables used in the analyses; the $\Gamma_{i} \Delta X_{t-i}$ terms reflect the short-run relationships among elements of the $X_{t}$ matrix; the $\Pi$ matrix captures the long-run relationships among the variables; the rest are deterministic terms including shift (intervention: $D_{t-k}$ ) and impulse (indicator: $\Delta D_{t-i}$ ) dummies, trend $(t)$, trend and shift dummy interaction terms and centered seasonal dummies $\left(s_{i}\right)$.

Regarding the presence of structural breaks, we employ the Clemente et al. (1998) test as follows. This test includes controls for shift and impulse dummies in addition to lagged dependent variable, and t-ratio is calculated for every possible combination for structural breaks (in case of two structural break dates). The structural break date or combination of dates minimizing estimated t-ratio is chosen as the break dates. If 
the absolute value of min-t statistic is less than the absolute value of five percent of the critical value, the null hypothesis of the unit root for price series is not rejected. ${ }^{[2]}$

\section{Data description, Econometric Model, and Results}

The data used in this study was collected and published officially by the Turkish Statistical Institute. We use producer and retail prices from January 2003 to December 2013. Producer prices reported for whole chickens include both the price of sub-contractors and the internal prices of vertically integrated firms targeted by the CA. Even the sub-contracting firms are factory farms, hence we prefer "producer price" instead of "farm-gate price." All prices are in Turkish Lira per kilogram for chicken. We use a logarithm of nominal prices in the analysis (PPRODUCER and PRETAIL). The supply shifter is a composition of feed and energy prices, the major constituents of production costs. Hence, we use a combination of feed and energy costs for the supply shifter (FEED_ENERGY). ${ }^{[3]}$ The consumer price index (CPI) is included in the model as a demand shifter. Lloyd et al. (2009) argue that in Equation 2, income would be an ideal demand shifter, but monthly income data is not available. So, instead, they suggest using the retail food index as a proxy for the demand shifter. We also followed their strategy and used the Consumer Food Price Index as a proxy for the demand shifter $(2003=100)$. Table 1 shows the summary statistics for the price series.

Table 1

\section{Summary Statistics of Variables Used}

\begin{tabular}{l|c|c|c|c|c}
\hline & PRETAIL & PPRODUCER & MC & CPI & FEED_ENERGY \\
\hline Mean & 1.509 & 0.995 & 5.027 & 5.029 & 5.034 \\
\hline Median & 1.573 & 0.825 & 4.972 & 5.057 & 5.052 \\
\hline Maximum & 2.029 & 1.586 & 5.786 & 5.489 & 5.546 \\
\hline Minimum & 0.963 & 0.491 & 4.328 & 4.582 & 4.575 \\
\hline Std. Dev. & 0.317 & 0.350 & 0.423 & 0.280 & 0.297 \\
\hline Skewness & -0.168 & 0.593 & 0.286 & -0.019 & 0.261 \\
\hline Kurtosis & 1.612 & 1.737 & 1.867 & 1.636 & 1.855 \\
\hline \multicolumn{7}{|c|}{10.041} & 16.251 & 8.719 & 10.091 & 8.579 \\
\hline Jarque-Bera & 11.040 & 0.013 & 0.006 & 0.014 \\
\hline Probability & 0.004 & 130 & 130 & 130 & 130 \\
\hline
\end{tabular}

Source: TurkStat (2013a and b)

[2] We also test for the presence of a unit root with a structural break following Saikkonen and Lütkepohl (2002). It is a simpler procedure where the largest change from month-to-month is selected as structural break date. Once shift date is known, they suggest first estimating $y_{t}=a_{0}+a_{1} t+a_{2} D+e_{t}$ where $D$ is a dummy variable for structural break test, and subtracting that from the original series. Then, the ADF test is performed on the adjusted series.

${ }^{[3]}$ Lloyd et al. (2009) and Falkowski (2010) use the price index for all goods and services purchased by farmers. The Turkish Statistical Institute does not produce such an index, so we created an index from the two most widely used inputs in farming feed and energy, excluding labor. 
Lloyd et al. (2009) use an index of average earnings in the retail sector as a proxy for marketing costs and Falkowski (2010) uses wages in the agri-food processing. The series mentioned above are available only quarterly for Turkey. We chose the processing and preserving of meat and production of meat products as a proxy for marketing costs and interpolated the quarterly data linearly to transform it into monthly values (use of cubic spline interpolation resulted in almost identical values). The marketing cost (MC), demand (CPI), and supply (FEED_ENERGY) shifter are presented in Figure 2.

Figure 2

\section{Natural logs of Consumer Price Index (CPI), Feed and Energy Cost (FEED_ENERGY), and Marketing Cost (MC)}

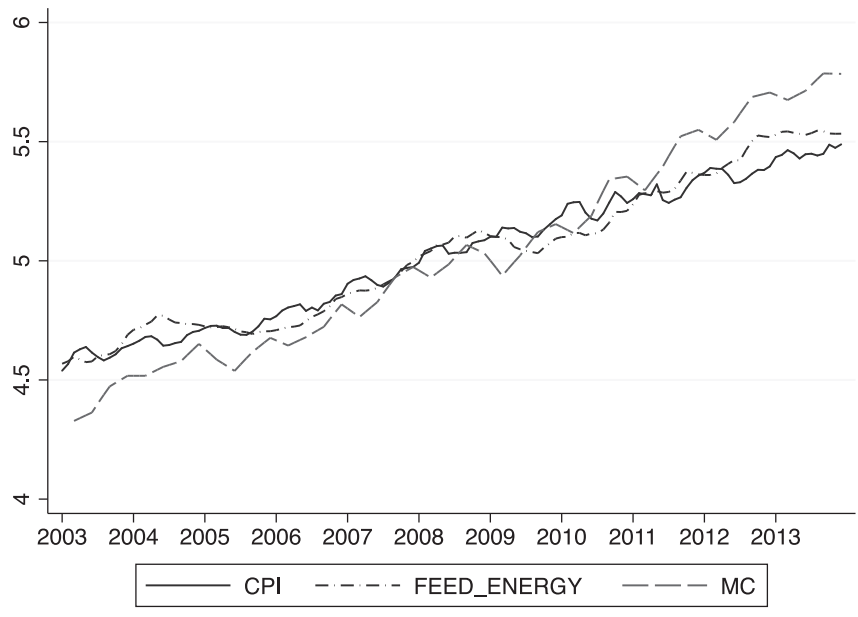

\section{Temporal Properties of Chicken Price Series}

To specify the VECM model, several time-series properties of the data need to be analyzed. These include conducting unit-root tests, determining the presence of deterministic trends, choosing the appropriate lag length, testing for the presence of structural breaks, and identifying the cointegration space.

First, the temporal properties of the price series are analyzed using an augmented Dickey-Fuller test (ADF) and, as a second test, we also present the results of the Kwiatkowski, Phillips, Schmidt, and Shin KPSS test (Kwiatkowski et al., 1992). Considering the way the variables behave, a constant and a linear trend are included in the tests. The KPSS results are also presented mainly for the reason that the inclusion of a trend term may decrease the power of the ADF test (Lloyd et al. 2009). Note that Lloyd et al. (2009) attribute the inconsistency in unit root test results to working with finite samples, and that the provision of the random walk model is an imperfect approximation of the data. The ADF and KPSS unit-root tests failed to reject the null hypothesis of a unit root, indicating that all the series in Equation 2 are non-stationary in levels except the retail price. After first-differencing and re-estimating (see the KPSS results), the results rejected the null hypothesis of a unit root at the one percent level of significance for the 
model variables, showing the series to be stationary. Regarding the retail price, a test is run to find out whether the series is trend stationary or follows a unit-root process containing a drift term (Enders, 2004: 193). The results indicate that the retail price is a trend stationary process. The results of the ADF and KPSS tests are presented in Table 2.

Table 2

ADF and KPSS Tests (with intercept and trend)

\begin{tabular}{l|c|c|c|c}
\hline & \multicolumn{2}{|c|}{ ADF } & \multicolumn{2}{c}{ KPSS } \\
\hline & Levels & Differences & Levels & Differences \\
\hline PRETAIL & $-3.93 * *$ & $-11.26 * * *$ & $0.12 *$ & $0.50 * * *$ \\
\hline PPRODUCER & 0.51 & $-16.09 * * *$ & $0.25 * * *$ & 0.07 \\
\hline MC & -2.71 & -2.56 & $0.26 * * *$ & 0.04 \\
\hline CPI & $-4.82 * * *$ & $-7.73 * * *$ & $0.16^{* *}$ & 0.07 \\
\hline FEED_ENERGY & -2.32 & $-6.61 * * *$ & $0.15 * *$ & 0.05 \\
\hline $\begin{array}{l}\text { For ADF test } * \text { denotes rejection of the unit root at } 10 \%, * * \text { at } 5 \%, \text { and } * * * \text { at } 1 \% \text { levels } \\
\text { For KPSS test } * \text { denotes rejection of the stationarity at } 10 \%, * * \text { at } 5 \%, \text { and } * * * \text { at } 1 \% \text { levels }\end{array}$
\end{tabular}

Johansen et al. (2000) state that care should be given to cointegration models with known structural breaks. To test for the presence of structural breaks, we employ the test developed by Clemente et al. (1998). We believe that the additive outlier model better fits the visual inspection of our data. However, we also test for the alternative, the innovative outlier model; and the results are the same, we fail to reject the null hypothesis of unit root. For structural break dates, both tests indicate the end of 2009; however, the sudden jump in producer prices at the end of 2009 is very short-lived. The visual inspection of data and the Saikkonen and Lütkepohl (2002) methodology suggests January 2011 as the structural break date. We choose January 2011 as the structural break date and incorporate it in our VEC model. The results for the presence of a structural break are presented in Table 3.

Table 3

Testing Natural Log of Producer Prices for Unit Root with Single Mean Shifts (Additive Outlier Model)

\begin{tabular}{l|c|c}
\hline & Additive & Innovative \\
\hline constant & 0.75 & 0.11 \\
\hline $\mathrm{d} 1$ & 0.67 & 0.1 \\
\hline \multicolumn{1}{c|}{$\mathrm{t}-\mathrm{d} 1$} & 26 & 3.1 \\
\hline $\mathrm{rho}=-1$ & -0.28 & -0.14 \\
\hline \multicolumn{1}{c|}{$\min -\mathrm{t}$} & -2.78 & -2.95 \\
\hline $\mathrm{T} \quad 118$ & 118 \\
\hline $\mathrm{d} 1 \mathrm{n}$ & $2009 \mathrm{~m} 12$ & $2009 \mathrm{~m} 9$ \\
\hline
\end{tabular}




\section{Market Power Estimation}

As pointed out in Enders (2004), when the series follow I(1) processes, Johansen's cointegration test is used to investigate the possibility of an equilibrium. The ADF and KPSS test results suggest that a VEC model is appropriate for characterizing the multivariate relationships among the two price series and MC, CPI, FEED_ENERGY (Engle and Granger, 1987). For the VEC model presented in Equation (3) that will be used in the Lloyd et al. (2009) estimation, having considered the fits provided by alternative models, we have decided to use the model with an unrestricted constant and a restricted trend in the cointegrating equation. With the presence of structural breaks, the critical values for the trace statistic also need to be modified (Johansen et al., 2000). The critical values of the trace statistic with one structural break are obtained by using the codes provided in Giles and Godwin (2011). To find the appropriate lag length while specifying the VEC model, alternative models are compared by investigating the presence of autocorrelation in the residuals, multivariate normality of the residuals, and stability of the system (Juselius, 2006). Using general-to-specific modeling that starts with 13 lags, at the end, following the selection criteria described above, twelve lags are found to be optimal for the Lloyd et al. (2009) estimation.

At the five percent level of significance for the trace test (Johansen and Juselius, 1992), we reject the null hypotheses that $r=0$ or $r=1$. Hence, the cointegrating rank of the system is at most two at the five percent level. These results suggest there are two long-run equilibrium relationships between the chicken prices, marketing cost and demand and supply shifters. The cointegrating vectors provide the foundation to empirically address long-run relations. The cointegration test statistics calculated are presented in Table 4.

Table 4

Cointegration Test Statistics

\begin{tabular}{l|c|c|c}
\hline Number of CE & Maximal & Trace & \\
\hline & Eigenvalue & statistic & $\mathbf{5 \%} \mathbf{C V}$ \\
\hline None $*$ & 210.75 & 125.32 & 110.82 \\
\hline At most 1 & 96.90 & 83.37 & 81.74 \\
\hline At most 2 & 33.57 & 46.13 & 56.70 \\
\hline At most 3 & 17.83 & 18.39 & 35.49 \\
\hline At most 4 & 7.61 & 5.92 & 17.94 \\
\hline
\end{tabular}

*denotes significance at $5 \%$ level.

Critical values for linear deterministic component are derived by using Giles and Godwin (2011)

Finally, in the context of the cointegration model, in order to test the null hypothesis of perfect competition, we estimated the coefficients in Equation 2 as follows: Given the presence of a cointegrating vector derived above, the parameters of this vector are normalized on retail prices (Lloyd et al. 2009), and the estimation results are presented in Table 5 while the graph of the cointegrating relation is presented in Figure 3. 
Table 5

The Cointegrating Vector Normalized on Retail Prices

\begin{tabular}{l|c|c|c|c|c|c|c}
\hline & PRETAIL & Constant & PPRODUCER & MC & CPI & FEED_ENERGY & @ Trend \\
\hline Estimate & 1 & 9.28 & 0.02 & -0.79 & -1.19 & -0.31 & 0.01 \\
\hline Std. Err. & & & 0.10 & 0.39 & 0.61 & 0.40 & 0.01 \\
\hline t-stat & & & 0.18 & $2.04 * *$ & $-1.94 *$ & -0.78 & $2.00^{* *}$ \\
\hline
\end{tabular}

* denotes significance at $10 \%$ level, ** denotes significance at $5 \%$ level

Figure 3

\section{Cointegrating Relation}

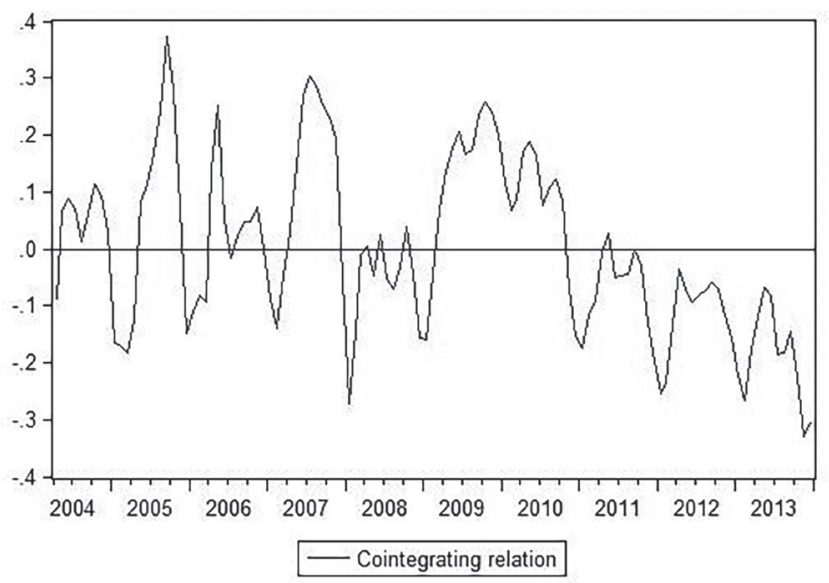

The estimates show that the coefficient of the producer price is statistically insignificant. The estimate of marketing cost has the expected sign and is statistically significant. For the existence of market power, we specifically focus on the estimated coefficients of demand and supply shifters. The coefficient of the demand shifter is statistically significant at the ten percent level (with a p-value of 0.055) and has the correct sign, but the coefficient of the supply shifter is insignificant. The null hypothesis of perfect competition, $H_{0}: \gamma_{3}=\gamma_{4}=0$ is rejected at the 1 percent level (the p-value is 0.000 ). Based on this "first-pass test" the rejection of the null hypothesis suggests that the behavior of the producer-retail price spread in the Turkish chicken marketing chain is consistent with the existence of an oligopolistic behavior and buyer power. In passing, note that Lloyd et al. (2009) also reject the same null hypothesis for beef, chicken, lamb, and pork in the U.K.

\section{Historical Decomposition Graphs}

To analyze the behavior of chicken prices more closely, we use historical decomposition graphs to look at prices between April 2009 and December 2009, around the time when the CA decision is announced. The historical decomposition tracks the evolution 
of the change through the system and traces forecasted prices in the absence of the change versus the actual prices that include the effects of market changes. Comparing the forecasted prices (without the change) with the actual prices provides a measure of the change impact. The historical decomposition graphs are based on partitioning the moving average series into two parts:

$$
P_{t+j}=\sum_{s=0}^{j-1} \psi_{s} U_{t+j-s}+\left[X_{t+j} \beta+\sum_{s=j}^{\infty} \psi_{s} U_{t+j-s}\right]
$$

where $P_{t+j}$ is the multivariate stochastic process for an agricultural price, $U$ is its multivariate noise process, $X$ is the deterministic part of $P_{t+j}$, and $s$ is a counter for the number of time periods (RATS, 2006; Fackler and McMillin, 2002). The first sum represents that part of $P_{t+j}$ due to innovations that drive the joint behavior of prices for the period $t+1$ to $t+j$, the horizon of interest. The second part is the forecasted price series based on information available at time $t$, the date of an event; that is, how prices would have evolved if there had been no changes (RATS, 2006). The noise process is included in both parts, but for two different time periods. It drives the moving average for the two partitions, one for the process that incorporates the change, and the other for the purpose of forecast estimates.

Figure 4

\section{Historical Decomposition of Retail (PRETAIL) and Producer (PPRODUCER) \\ Chicken Prices in 2009}

Historical Decomposition of PRETAIL

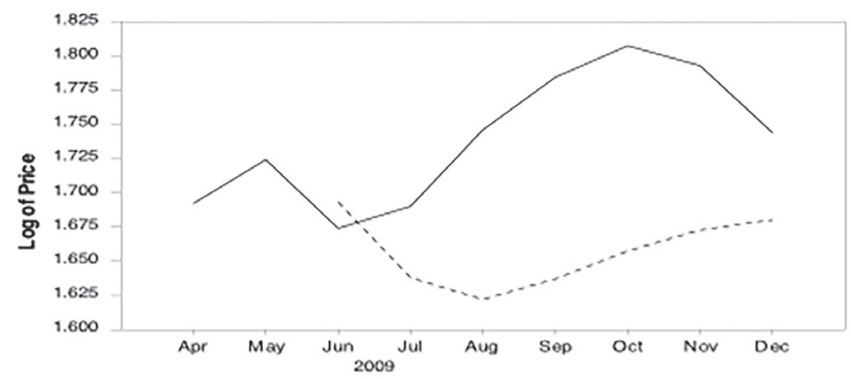

Historical Decomposition of PPRODUCER

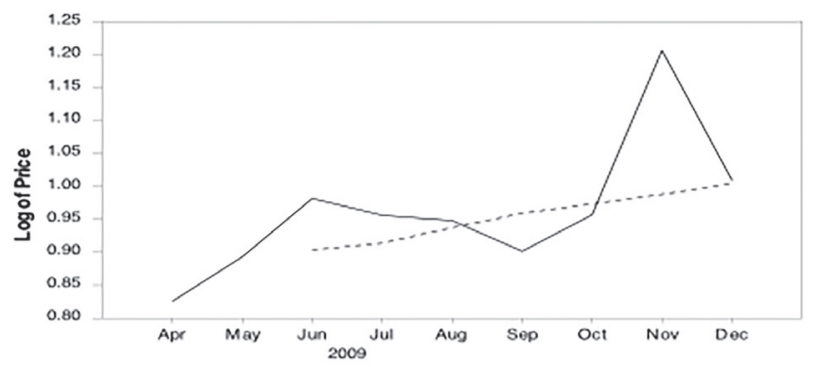


The results show (Figure 4) that while the expectation was for the chicken retailers to decrease their prices in June 2009 due to the CA report (the dashed line predicts the prices but excludes the impact of the news), they actually increased their prices (the solid line - the actual price that includes the news). A comparison between the two series clearly shows the higher retail prices charged compared to producer prices (PPRODUCER), an indication of downstream buyer power. The results show the actual price charges were almost 15\% higher than the forecasted prices in October 2009, an indication of increased profits and loss of consumer surplus. During the second half of $2009,650,000$ tons of broiler chicken meat was consumed. The fifteen percent inflated retail price suggests an $0.8 \mathrm{TL} / \mathrm{kg}$ overcharge, equaling more than half a billion Turkish Lira (or 350 million USD at the nominal exchange rates).

\section{Conclusions and Policy Recommendations}

In 2009, the Competition Authority in Turkey penalized 27 broiler chicken producers for their cartel-like behavior. In this study, we investigated the presence of market power by focusing on the widening of the producer-retail price spread. We tested the presence of oligopolistic behavior and imperfect competition by incorporating exogenous demand and supply shifters into the producer-retail price spread equation. The results rejected the null hypothesis of perfect competition at the retail level. The rejection of this hypothesis is an indication of imperfect competition and market power in the downstream Turkish poultry sector. This finding can be attributed to the existence of the supermarket chains' buyer power vis-à-vis the broiler chicken producers. The CA report was silent on the behavior of retailers. The CA could have devoted more resources to the analysis of retail price formation before announcing its final decision.

The use of historical decomposition graphs for the broiler chicken market revealed that higher retail prices were charged over producer prices, another indication of market power at the retail level. Overall, the results showed the retail price behavior was consistent with an oligopolistic market structure in the poultry sector in Turkey, resulting in a significant consumer surplus loss. These results raise public concerns and have policy and welfare implications.

Considering food security and availability in Turkey, crucial roles are assigned to policy makers and regulatory agencies. An important policy goal is the provision of meat products for consumers at affordable prices. In particular, consumers in developing countries need access to protein in forms of poultry products without having to allocate an undue share of their consumption budget for it. The existence of imperfect competition in the poultry sector burdens consumers with higher prices and a loss of consumer surplus. The regulatory agencies need to pay closer attention to producer-retail price policies, rather than just focusing on the analysis of anti-competitive behavior due to horizontal integration. The policy makers in Turkey can expand their oversight and regulation of the poultry sector in order to increase the competition and efficiency of the supply chain. 
Until very recently, animal product markets in Turkey were generally kept separate from global markets due to import barriers. These markets were only indirectly linked to global markets through animal feed imports. As Turkish animal product markets become more and more linked to global markets, studies focused on price dispersion from global to Turkish market will probably be needed. Also, currently, it is not possible to investigate distributional effects and regional variation effects of price gauging by intermediaries owing to data limitations. This paper has analyzed the Turkish poultry market as a single entity by limiting the research to monthly prices due to data limitations. However, there is dearth of studies on the spatial dispersion of prices within Turkey which requires a weekly regional price series. Moreover, monthly quantity data has only recently become available; therefore there is not enough data available to analyze the distributional effects of price gauging. Future studies and policy development concerning the animal products markets would benefit greatly from improved data gathering and sharing by relevant national agencies.

\section{References}

Bakucs, L.Z. and Ferto, I. (2005). "Marketing Margins and Price Transmission on the Hungarian Pork Meat Market," Agribusiness, 21(2): 273-286.

Cavicchioli, D. (2010). "Detecting Market Power Along Food Supply Chains: Evidence from the Fluid Milk Sector in Italy," Paper presented at the $116^{\text {th }}$ EAAE Seminar, October 27-20, 2010, Parma, Italy.

Clemente, J. Montañés, A., and Reyes, M. (1998). "Testing for a Unit Root in Variables with a Double Change in the Mean," Economic Letters 59: 175-182.

Cotterill, R.W. (2005). "The Impact of the Northeast Dairy Compact on New England Consumers: A Report from the Milk Policy Wars.” Agribusiness, 21(4): 455-471.

Enders, W. (2004). Applied Econometric Time Series, Second Edition. New York: John Wiley and Sons, Inc.

Engle, R.F. and Granger, C.W.J. (1987). "Co-Integration and Error Correction: Representation, Estimation, and Testing," Econometrica, 55(2): 251-276.

Erdoğan, T., Akkaya, M.B., Ünübol, N., İnce, E., and Işık, S. (2012). Türkiye Hızlı Tüketim Malları Perakendeciliği Sektör İncelemesi Nihai Raporu (Fast Moving Consumer Goods Retailing in Turkey: Final Report). Ankara: Rekabet Kurumu (Competition Authority). Available [online] at: http://www. rekabet.gov.tr/dosyalar/sektorraporlari/sektorrapor7.pdf.

FAOSTAT. (2013). http://faostat3.fao.org/faostat-gateway/go/to/download/C/CL/E (Access November 2013)

Fackler J.F. and McMillin, W.D. (2002). "Evaluating Monetary Policy Options," Southern Economic Journal, 68(4): 794-810.

Falkowski, J. (2010). "Price Transmission and Market Power in a Transition Context: Evidence from the Polish Fluid Milk Sector," Post-Communist Economies, 22(4): 513-529.

Frey, G. and Manera, M. (2007). "Econometric Models of Asymmetric Price Transmission," Journal of Economic Surveys, 21(2): 349-415.

Giles, D.E. and Godwin, R.T. (2011). "Testing for Multivariate Cointegration in the Presence of Structural Breaks: p-Values and Critical Values," University of Victoria, Department of Economics, Econometrics Working Paper EWP1110. 
Johansen, S. and Juselius, K. (1992). "Testing Structural Hypothesis in a Multivariate Cointegration Analysis of the PPP and UIP for the UK," Journal of Econometrics. 53: 211-244.

Johansen, S., Moscow, R., and Nielsen, B. (2000). "Cointegration Analysis in the Presence of Structural Breaks in the Deterministic Trend," Econometrics Journal, 3: 216-249.

Joyeux, R. (2001). "How to Deal with Structural Breaks in Practical Cointegration Analysis,"

Available at:http://www.econ.mq.edu.au/Econ_docs/research_papers2/2001/12-2001b.pdf

Juselius, K. (2006). The Cointegrated VAR Model: Methodology and Applications. Oxford University Press.

Kinnucan, H.W. and Tadjion, O. (2013). "Theoretical Restrictions on Farm-Retail Price Transmission Elasticities: A Note," Agribusiness, doi: 10.1002/agr.21362

Kwiatkowski, D., Phillips, P.C.B., Schmidt, P., and Shin, Y. (1992). "Testing the Null Hypothesis of Stationarity against the Alternative of a Unit Root," Journal of Econometrics, 54(1/3): 159-178.

Liu, X. (2012). "Empirical Research on Spatial and Time Series Properties of Agricultural Commodity Prices," Ph.D. Dissertation, Hanken School of Economics, Helsinki, Finland.

Lloyd, T., McCorriston, D., Morgan, W., Rayner, A., and Weldegebriel, H. (2009). "Buyer Power in U.K. Food Retailing: A 'First-Pass' Test," Journal of Agricultural and Food Industrial Organization, 7, Article 5.

Meyer, J. and von Cramon-Taubadel, S. (2004). “Asymmetric Price Transmission: a Survey,” Journal of Agricultural Economics, 55(3): 581-611.

RATS User's Guide. (2006). Version 6, Estima.

Saikkonen P. and Lütkepohl, H. (2002). "Testing for a Unit Root in a Time Series with a Level Shift at an Unknown Time," Econometric Theory, 18: 313-348.

Turkish Competition Authority. (2009). "Determining whether 27 undertakings operating in the white meat market and the Association of the Union of White Meat Industrialists and Breeders violated Article 4 of the Act No. 4054," Decision No: 10-73/1509-577.

TurkStat. (2013a). Turkish Statistical Institute Agricultural Prices Website. Available [online] at: http://tuik.gov.tr/VeriBilgi.do?alt_id=50.

-----, (2013b). Producer Prices::http://tuikapp.tuik.gov.tr/ufedagitimapp/ (Access October 2013). 